\title{
Methylobacterium platani sp. nov., isolated from a leaf of the tree Platanus orientalis
}

Correspondence

Woojun Park

wpark@korea.ac.kr

\section{Yoon-Suk Kang, ${ }^{1}$ Juhyun Kim, ${ }^{1}$ Hyeon-Dong Shin, ${ }^{1}$ Young-Do Nam, ${ }^{2}$ Jin-Woo Bae, ${ }^{2}$ Che Ok Jeon ${ }^{3}$ and Woojun Park ${ }^{1,3}$}

\author{
${ }^{1}$ Division of Environmental Science and Ecological Engineering, Korea University, Seoul, \\ South Korea \\ ${ }^{2}$ Biological Resource Center, KRIBB, Daejeon, South Korea \\ ${ }^{3}$ Environmental Biotechnology National Core Research Center, Gyeongsang National University, \\ Jinju, South Korea
}

The genus Methylobacterium mainly consists of pinkpigmented, facultatively methylotrophic bacteria. The genus belongs to the class Alphaproteobacteria and the cells are strictly aerobic, Gram-negative rods that are able to grow on a range of carbon substrates and are also able to utilize single-carbon $\left(\mathrm{C}_{1}\right)$ compounds (such as formate, formaldehyde and methanol) as sole sources of carbon and energy (Lidstrom \& Chistoserdova, 2002). Members of the genus Methylobacterium are ubiquitous in nature, being found in soils, dust and lake sediments. They have also been found in association with plants, specifically leaf surfaces, and it has been hypothesized that they potentially dominate phyllospheric bacterial populations (Corpe \& Basile, 1982; Hirano \& Upper, 1991). The genus Methylobacterium was first described by Patt et al. (1976) and at the time of writing consists of the following 24 recognized species (http://www.bacterio.cict.fr/m/methylobacterium.

The GenBank/EMBL/DDBJ accession number for the 16S rRNA gene sequence of strain $\mathrm{PMBO}^{\top}$ is EF426729.

Photomicrographs of cells of strain $\mathrm{PMBO}^{\top}$, DNA-DNA hybridization data and fatty acid profiles for strain $\mathrm{PMBO}^{\top}$ and related strains are available as supplementary material with the online version of this paper. html): Methylobacterium adhaesivum (Gallego et al., 2006), M. aminovorans (Urakami et al., 1993), M. aquaticum (Gallego et al., 2005a), M. chloromethanicum (McDonald et al., 2001), M. dichloromethanicum (Doronina et al., 2000), M. extorquens (Bousfield \& Green, 1985), M. fujisawaense (Green et al., 1988), M. hispanicum (Gallego et al., 2005a), M. isbiliense (Gallego et al., 2005c), M. jeotgali (Aslam et al., 2007), M. lusitanum (Doronina et al., 2002), M. mesophilicum (Green \& Bousfield, 1983), M. nodulans (Jourand et al., 2004), M. organophilum (Patt et al., 1976), M. oryzae (Madhaiyan et al., 2007), M. podarium (Anesti et al., 2004), M. populi (Van Aken et al., 2004), M. radiotolerans (Green \& Bousfield, 1983), M. rhodesianum (Green et al., 1988), $M$. rhodinum (Green \& Bousfield, 1983), M. suomiense (Doronina et al., 2002), M. thiocyanatum (Wood et al., 1998), M. variabile (Gallego et al., 2005b) and M. zatmanii (Green et al., 1988). Here, we provide a detailed taxonomic characterization of a Methylobacterium-like bacterial strain, $\mathrm{PMB}^{\mathrm{T}}{ }^{\mathrm{T}}$, which was isolated from a tree leaf.

Strain $\mathrm{PMB} 02^{\mathrm{T}}$ was isolated from a leaf from a Platanus orientalis tree at Korea University, Seoul, Korea, and cultivated on a potato dextrose agar (Difco) plate at room temperature. After initial cultivation, cells were maintained 
on TYG medium ( $0.5 \%$ tryptone, $0.25 \%$ yeast extract and $0.1 \%$ glucose) at $30{ }^{\circ} \mathrm{C}$. For phenotypic characterization, growth on TYG medium at various temperatures $(4,10,20$, $25,30,33$ and $\left.37{ }^{\circ} \mathrm{C}\right)$ and different $\mathrm{pHs}(4,5,6,7,8$ and 9) was measured for 3 days. The optimum temperature range was $25-30{ }^{\circ} \mathrm{C}$, but growth did occur at $20-30{ }^{\circ} \mathrm{C}$. The optimum $\mathrm{pH}$ for growth was between 6.0 and 7.0, but growth could occur between $\mathrm{pH} 6.0$ and 8.0. Cellular morphology and motility were determined microscopically (Filter set 20 Rhod; Carl Zeiss). Cells of strain PMB02 ${ }^{\mathrm{T}}$ were Gram-negative, aerobic, motile rods (1.4-1.5 $\times 2.0$ $6.5 \mu \mathrm{m}$ ) that occurred singly, in pairs or in rosettes (on TYG medium for $48 \mathrm{~h}$ at $30{ }^{\circ} \mathrm{C}$ ). When strain $\mathrm{PMB} 02^{\mathrm{T}}$ was incubated on TYG medium $(\mathrm{pH} 7.0)$ at $30{ }^{\circ} \mathrm{C}$ at 220 r.p.m., the growth rate was $0.24 \pm 0.04$ cells $^{-1}$. Colonies of strain $\mathrm{PMB} 02^{\mathrm{T}}$ were circular in shape, pink in colour and $0.2-1.5 \mathrm{~mm}$ in diameter when grown on TYG agar for at least 2-3 days. Interestingly, colonies of some Methylobacterium species, such as M. jeotgali (Aslam et al., 2007) and M. nodulans (Jourand et al., 2004), are non-pigmented. MSB medium (Stanier et al., 1966) was used for the utilization of sole $\mathrm{C}_{1}$ sources, such as methanol and formaldehyde. Each carbon source was tested at concentrations of $0.01,0.05,0.1,0.5$ and $1.0 \%(\mathrm{v} / \mathrm{v})$. Strain $\mathrm{PMBO2}^{\mathrm{T}}$ was able to grow well with $0.1 \%$ methanol and $0.01 \%$ formaldehyde as sole carbon sources. To evaluate $\mathrm{NaCl}$ tolerance, cells were grown for 3 days in TYG medium containing $0,0.5,1,2$ and $3 \% \mathrm{NaCl}$. Strain $\mathrm{PMB} 02^{\mathrm{T}}$ is a slow-growing organism that does not grow in the presence of $\geqslant 1 \% \mathrm{NaCl}$. M. aquaticum CCM $7218^{\mathrm{T}}$ (Gallego et al., 2005a) and M. variabile GR3 ${ }^{\mathrm{T}}$ (Gallego et al., 2005c) also do not grow in the presence of $\geqslant 1 \% \mathrm{NaCl}$, but M. lusitanum (Doronina et al., 2002) and M. suomiense (Doronina et al., 2002) can grow in the presence of $3 \%$ $\mathrm{NaCl}$ (Table 1). To investigate whether strain $\mathrm{PMB} 02^{\mathrm{T}}$ produced polyhydroxyalkanoates, cells were grown in TYG medium for $72 \mathrm{~h}$, then washed twice with PBS and transferred to modified MSB medium containing succinate $(10 \mathrm{mM})$. After $16 \mathrm{~h}$, cells were harvested, stained with Nile blue A (Ostle \& Holt, 1982) and then washed with water (to remove excess stain) and then with $100 \%$ ethanol for $1 \mathrm{~min}$; the cells were then observed using a fluorescence microscope (Filter set 20 Rhod). Strain $\mathrm{PMB} 02^{\mathrm{T}}$ accumulated polyhydroxyalkanoates when succinate was used as a carbon source (see Supplementary Fig. S1, available in IJSEM Online). Oxidase activity was tested using $1 \%$ (w/v) $N, N, N^{\prime}, N^{\prime}$-tetramethyl-p-phenylenediamine dihydrochloride: $10 \mu \mathrm{l}$ reagent was dropped onto culture on a glass slide. A positive reaction is shown by a colour change to violet or purple within $20 \mathrm{~s}$. Catalase activity was investigated by checking for the production of bubbles in a $3 \%(\mathrm{v} / \mathrm{v})$ hydrogen peroxide solution. Oxidase and catalase activities were detected in strain $\mathrm{PMB}_{2}{ }^{\mathrm{T}}$. Nutritional characteristics were determined

Table 1. Differential characteristics of strain $\mathrm{PMBO}^{\top}$ and the type strains of related species of Methylobacterium

Strains: 1, $\mathrm{PMB}_{2}{ }^{\mathrm{T}}$; 2, M. variabile GR3 ${ }^{\mathrm{T}}$ (Gallego et al., 2005c); 3, M. aquaticum CCM $7218^{\mathrm{T}}$ (Gallego et al., 2005a); 4, M. lusitanum NCIMB $13799^{\mathrm{T}}$ (Doronina et al., 2002); 5, M. suomiense NCIMB $13778^{\mathrm{T}}$ (Doronina et al., 2002); 6, M. populi NCIMB 13946 ${ }^{\mathrm{T}}$ (Van Aken et al., 2004). All strains are motile. ND, Not determined; + , positive; - , negative.

\begin{tabular}{|c|c|c|c|c|c|c|}
\hline Characteristic & 1 & 2 & 3 & 4 & 5 & 6 \\
\hline Cells form pairs & + & + & + & Rarely & Rarely & + \\
\hline Cells form rosettes & + & + & + & - & - & + \\
\hline Cell length $(\mu \mathrm{m})$ & $2.0-6.5$ & $2-6$ & $4.5-8$ & $1.7-2$ & $1.2-2.5$ & $1-10$ \\
\hline Cell width $(\mu \mathrm{m})$ & $1.4-1.5$ & $1-1.5$ & $1.5-1.7$ & $1-1.2$ & $0.8-1$ & $0.8-1$ \\
\hline Pigmentation & Pink & Pink & Pink, red & Pink & Pink & Pink, red \\
\hline Colony diameter $(\mathrm{mm})$ & $0.2-1.5$ & $2-7$ & $1-2$ & 1 & $0.5-1$ & $0.1-0.2$ \\
\hline Oxidase & + & - & - & + & + & + \\
\hline Tolerance of $\mathrm{NaCl}(\%)$ & 1 & 1 & 1 & 3 & 3 & 2 \\
\hline Ubiquinone & Q-10 & ND & ND & Q-10 & Q-10 & ND \\
\hline Optimal temperature $\left({ }^{\circ} \mathrm{C}\right)$ & $25-30$ & 28 & 28 & $30-37$ & $25-30$ & $20-30$ \\
\hline $\mathrm{pH}$ range & $6.0-8.0$ & $5.0-8.0$ & $5.0-7.0$ & $6.9-7.5$ & $6.9-7.5$ & $5.0-8.0$ \\
\hline Major fatty acid & cis-Vaccenic acid & cis-Vaccenic acid & cis-Vaccenic acid & cis-Vaccenic acic & cis-Vaccenic acid & Oleic acid \\
\hline DNA G $+\mathrm{C}$ content $(\mathrm{mol} \%)$ & 68.5 & 69.2 & 67.5 & 66.5 & 65.8 & 70.4 \\
\hline \multicolumn{7}{|l|}{ Hydrolysis of: } \\
\hline Tween 40 & - & - & + & ND & ND & ND \\
\hline Tween 80 & - & - & + & ND & ND & ND \\
\hline \multicolumn{7}{|l|}{ Assimilation of: } \\
\hline L-Arabinose & + & - & - & - & - & - \\
\hline L-Asparagine & - & + & + & ND & ND & ND \\
\hline L-Fucose & - & + & + & ND & ND & - \\
\hline D-Galactose & - & + & + & ND & ND & ND \\
\hline D-Glucose & - & + & + & - & + & - \\
\hline
\end{tabular}


using the Biolog GN2 system (Gallego et al., 2005b): Biolog GN microplates were inoculated with $125 \mu \mathrm{l}$ cell suspension per well and then incubated at $28{ }^{\circ} \mathrm{C}$ for 7 days. A summary of the phenotypic characteristics of $\mathrm{PMBO2}^{\mathrm{T}}$ in comparison with those of closely related Methylobacterium species is presented in Table 1 .

16S rRNA genes were PCR-amplified from DNA extracts using universal primers $27 \mathrm{f}$ ( $5^{\prime}$-AGAGTTTGATCCTGGCTCAG-3') and 1492r (5'-GGCTACCTTGTTACGACTT$3^{\prime}$ ), and were purified as described previously (Kim et al., 2005). The resulting $16 \mathrm{~S}$ rRNA gene sequence (1432 nt) of strain $\mathrm{PMB} 02^{\mathrm{T}}$ was compared with available $16 \mathrm{~S}$ rRNA gene sequences in GenBank by using the BLAST program (http://www.ncbi.nlm.nih.gov/BLAST/) to determine an approximate phylogenetic affiliation. Gene sequences were then aligned with those of closely related species using Clustal W (Thompson et al., 1994). Phylogenetic trees were constructed using the neighbour-joining, maximum-likelihood and maximum-parsimony algorithms, which are available in PHYLIP, version 3.6 (Felsenstein, 2002). 16S rRNA gene sequence comparisons for similarity calculations were made between the novel strain and related members of the genus Methylobacterium, using the FASTA3 program (European Bioinformatics Institute; http:// www.ebi.ac.uk/fasta33/nucleotide.html). Comparative 16S rRNA gene sequence analyses revealed that strain $\mathrm{PMB} 02^{\mathrm{T}}$ was phylogenetically affiliated to the genus Methylobacterium. Furthermore, the phylogenetic analysis based on $16 \mathrm{~S}$ rRNA gene sequences indicated that strain $\mathrm{PMB02}{ }^{\mathrm{T}}$ formed a phyletic lineage, within the genus Methylobacterium, with M. aquaticum CCM $7218^{\mathrm{T}}$ at a bootstrap value of $63.0 \%$ (Fig. 1). The topologies of the phylogenetic trees built using the maximum-likelihood and maximumparsimony algorithms also indicated that the isolate belongs to the genus Methylobacterium (data not shown). Comparative 16S rRNA gene sequence analyses showed that the isolate was most closely related to $M$. aquaticum CCM $7218^{\mathrm{T}}$ and M. variabile GR3 ${ }^{\mathrm{T}}$, with $16 \mathrm{~S}$ rRNA gene sequence similarities of 97.7 and $97.4 \%$, respectively. The sequence similarities with respect to other Methylobacterium species were less than $96.0 \%$. It has been suggested that bacterial strains with less than $97 \%$ 16S rRNA gene sequence identity represent novel species (Stackebrandt \& Goebel, 1994).

DNA-DNA hybridization was conducted to investigate the relatedness of strain $\mathrm{PMB} 02^{\mathrm{T}}$ with respect to its closest relatives, M. aquaticum CCM $7218^{\mathrm{T}}$ and $M$. variabile GR3 ${ }^{\mathrm{T}}$, using ${ }^{32} \mathrm{P}$-labelled DNA probes and the methods described by Ezaki et al. (1989). The genomic DNA of strain PMB02 ${ }^{\mathrm{T}}$ or M. aquaticum CCM $7218^{\mathrm{T}}$ was extracted using a genomic DNA-purification kit (Promega) and used as a probe (see Supplementary Table S1, available in IJSEM Online). Purified DNA $(1 \mathrm{mg})$ from strain $\mathrm{PMB}_{02} 2^{\mathrm{T}}$ or $M$. aquaticum CCM $7218^{\mathrm{T}}$ was labelled with ${ }^{32} \mathrm{P}$-labelled dCTP (PerkinElmer) and a random primer labelling kit (Invitrogen). The ${ }^{32} \mathrm{P}$-labelled DNA probe was then purified with a Nick column (Amersham Biosciences) through TE buffer (Tris-EDTA, pH 7.5). The genomic DNA was denatured by adding $0.4 \mathrm{M} \mathrm{NaOH}$ and $10 \mathrm{mM}$ EDTA and then heating the sample at $100{ }^{\circ} \mathrm{C}$ for $10 \mathrm{~min}$ (to ensure complete denaturation). The DNA was then neutralized by adding an equal volume of cold $2 \mathrm{M}$

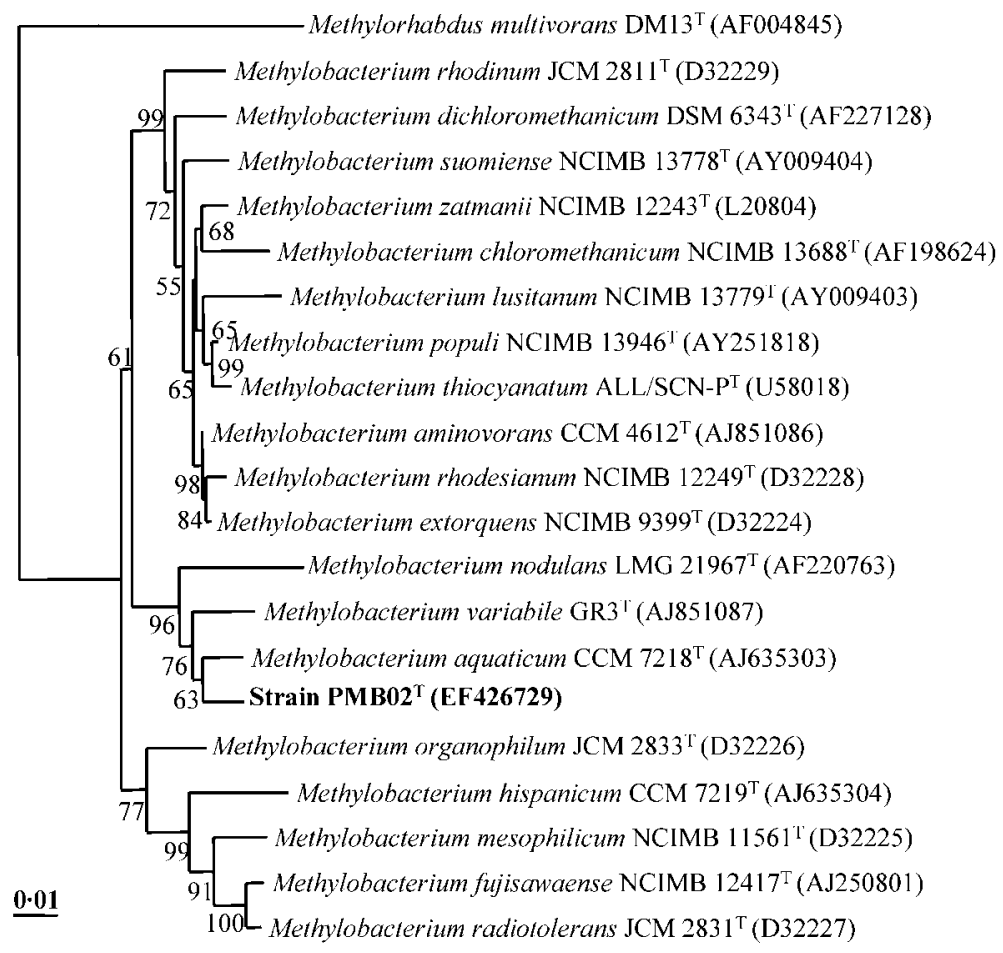

Fig. 1. Neighbour-joining phylogenetic tree, based on 16S rRNA gene sequences, showing the relationships between strain $\mathrm{PMBO}^{\top}$ and related taxa. Bootstrap percentages (based on 1000 replicates) are shown if greater than $50 \%$. Methylorhabdus multivorans $\mathrm{DM} 13^{\top}$ was used as an outgroup. Bar, 0.01 changes per nucleotide position. 
ammonium acetate ( $\mathrm{pH} 7.0)$. The DNA solutions (200 ng) were transferred onto a nylon membrane (Nytran N; Schleicher \& Schuell) using dot-blot apparatus (Bio-Rad). After the DNA had been filtered, the same volume of $0.4 \mathrm{M}$ $\mathrm{NaOH}$ was added to each well. The blotted membrane was rinsed in $2 \times$ SSC, air-dried and then irradiated at $254 \mathrm{~nm}$ to cross-link the DNA. Hybridization with the ${ }^{32} \mathrm{P}$-labelled DNA probes was conducted at $65{ }^{\circ} \mathrm{C}$. After hybridization, the nylon membrane was washed twice, first with $2 \times$ SSC and then with $0.1 \%$ SDS for $10 \mathrm{~min}$ at room temperature, then with $0.1 \times$ SSC and $0.5 \%$ SDS for $30 \mathrm{~min}$ at $65{ }^{\circ} \mathrm{C}$, to remove the unbound probe. The level of DNA-DNA relatedness $(\%)$ was calculated as $100\left(I_{R} / I_{T}\right)$, where $I_{R}$ is the intensity of hybridization of reference strains and $I_{\mathrm{T}}$ is the intensity of hybridization of the tested strain. The DNADNA hybridization data showed that strain $\mathrm{PMB} 2^{\mathrm{T}}$ had DNA-DNA relatedness values of 31.3 and $29.0 \%$ with $M$. aquaticum $\mathrm{CCM} 7218^{\mathrm{T}}$ and $M$. variabile $\mathrm{GR} 3^{\mathrm{T}}$, respectively, when ${ }^{32} \mathrm{P}$-labelled $\mathrm{PMB} 02^{\mathrm{T}}$ DNA probes were used (see Supplementary Table S1). M. aquaticum CCM $7218^{\mathrm{T}}$ had DNA-DNA hybridization levels of 28.9 and $33.3 \%$ with strain $\mathrm{PMB} 02^{\mathrm{T}}$ and $M$. variabile $\mathrm{GR} 3^{\mathrm{T}}$, respectively, when ${ }^{32}$ P-labelled M. aquaticum CCM $7218^{\mathrm{T}}$ DNA probes were used. A hybridization value below $70 \%$ has been suggested as the threshold value for delineating a bacterial species (Wayne et al., 1987), so these data indicate that strain $\mathrm{PMB02}^{\mathrm{T}}$ represents a novel species of the genus Methylobacterium.

For the analysis of quinones and fatty acid methyl esters, cells were grown on TYG liquid medium at $30{ }^{\circ} \mathrm{C}$ for $48 \mathrm{~h}$. Fatty acids were extracted and prepared according to standard protocols provided with the MIDI/Hewlett Packard Microbial Identification System (Sasser, 1990). The following fatty acids were detected in strain $\mathrm{PMB} 02^{\mathrm{T}}$ (see Supplementary Table S2, available in IJSEM Online): $\mathrm{C}_{18: 1} \omega 7 c(81.0 \%), \mathrm{C}_{16: 0}(7.6 \%), \mathrm{C}_{18: 0} 3-\mathrm{OH}(3.46 \%)$, summed feature $3(2.24 \%)$ comprising $\mathrm{C}_{16: 1} \omega 7 c$, iso- $\mathrm{C}_{15: 0}$ 2-OH or both, summed feature $2\left(\mathrm{C}_{14: 0} 3-\mathrm{OH} /\right.$ iso- $\mathrm{C}_{16: 1} \mathrm{I}$, $1.98 \%)$ and $\mathrm{C}_{18: 0}(1.71 \%)$. Traces $(\leqslant 1.0 \%)$ of $\mathrm{C}_{14: 0}$, $\mathrm{C}_{18: 1} \omega 9 c, \mathrm{C}_{12: 0}, \mathrm{C}_{19: 0}$ 10-methyl, $\mathrm{C}_{14: 1} \omega 5 c, \mathrm{C}_{16: 0} \mathrm{~N}$ alcohol and $\mathrm{C}_{18: 3} \omega 6 c$ were detected. The major quinone of strain $\mathrm{PMB} 02^{\mathrm{T}}$ was $\mathrm{Q}-10$. The $\mathrm{G}+\mathrm{C}$ content of the genomic DNA was determined using HPLC analysis methods described previously (Mesbah et al., 1989). The DNA $\mathrm{G}+\mathrm{C}$ content of strain $\mathrm{PMB} 02^{\mathrm{T}}$ was $68.5 \mathrm{~mol} \%$, which falls within the range described for the genus Methylobacterium (Green, 1992).

\section{Description of Methylobacterium platani sp. nov.}

Methylobacterium platani (pla.ta'ni. L. gen. n. platani of Platanus orientalis, referring to the tree species from which the micro-organism was isolated).

Cells are Gram-negative rods measuring 1.4-1.5 $\times 2.0$ $6.5 \mu \mathrm{m}$, occurring singly, in pairs or in rosettes. Cells are motile and non-spore-forming. Cells are slow-growing on nutrient agar and TYG agar and produce small, smooth, pink-pigmented colonies. Methanol, formaldehyde and formate are utilized by strain $\mathrm{PMB} 02^{\mathrm{T}}$ as sole carbon sources. Does not grow in the presence of $\geqslant 1 \% \mathrm{NaCl}$. Positive for catalase and cytochrome oxidase. Optimum temperature range for growth is $25-30{ }^{\circ} \mathrm{C}$, but growth does occur at $20-30{ }^{\circ} \mathrm{C}$. Optimum $\mathrm{pH}$ for growth is between 6.0 and 7.0, but growth does occur between $\mathrm{pH} 6.0$ and 8.0. Oxidizes the following compounds as sole carbon and energy sources: L-arabinose, D-fructose, methyl pyruvate, monomethyl succinate, acetic acid, cis-aconitic acid, formic acid, D-galactonic acid lactone, D-galacturonic acid, Dgluconic acid, $\alpha$-hydroxybutyric acid, $\beta$-hydroxybutyric acid, $\gamma$-hydroxybutyric acid, $\alpha$-ketobutyric acid, $\alpha$-ketoglutaric acid, DL-lactic acid, propionic acid, quinic acid, Dsaccharic acid, sebacic acid, succinic acid, bromosuccinic acid, succinamic acid, L-aspartic acid, L-glutamic acid, Lproline and L-threonine. Does not utilize the following compounds as a carbon and energy source: $\alpha$-cyclodextrin, dextrin, glycogen, Tweens 40 and $80, \mathrm{~N}$-acetyl-D-galactosamine, $N$-acetyl-D-glucosamine, adonitol, D-arabitol, cellobiose, L-erythritol, L-fucose, D-galactose, gentiobiose, $\alpha$-D-glucose, myo-inositol, $\alpha$-D-lactose, lactulose, maltose, $\mathrm{D}$-mannitol, D-mannose, D-melibiose, methyl $\beta$-D-glucoside, D-psicose, D-raffinose, L-rhamnose, D-sorbitol, sucrose, trehalose, turanose, xylitol, citric acid, D-galacturonic acid, D-glucosaminic acid, D-glucuronic acid, $p$ hydroxyphenylacetic acid, itaconic acid, $\alpha$-ketovaleric acid, malonic acid, glucuronamide, alaninamide, D-alanine, Lalanine, L-alanyl glycine, L-asparagine, glycyl L-aspartic acid, glycyl L-glutamic acid, L-histidine, hydroxyl L-proline, L-leucine, L-ornithine, L-phenylalanine, L-pyroglutamic acid, D-serine, L-serine, DL-carnitine, $\gamma$-aminobutyric acid, urocanic acid, inosine, uridine, thymidine, phenylethylamine, putrescine, 2-aminoethanol, 2,3-butanediol, glycerol, DL- $\alpha$-glycerol phosphate, glucose 1-phosphate or glucose 6phosphate. Predominant cellular fatty acids are cis-vaccenic acid $\left(\mathrm{C}_{18: 1} \omega 7 c, 81.0 \%\right), \mathrm{C}_{16: 0} \quad(7.6 \%), \mathrm{C}_{18: 0} \quad 3-\mathrm{OH}$ $(3.46 \%)$, summed feature $3(2.24 \%)$ comprising $\mathrm{C}_{16: 1} \omega 7 c$, iso- $\mathrm{C}_{15: 0} 2-\mathrm{OH}$ or both, summed feature 2 $\left(\mathrm{C}_{14: 0} 3-\mathrm{OH} /\right.$ iso- $\left.\mathrm{C}_{16: 1} \mathrm{I}, 1.98 \%\right)$ and $\mathrm{C}_{18: 0}(1.71 \%)$. The major ubiquinone is Q-10. The DNA G $+\mathrm{C}$ content (by HPLC) is $68.5 \mathrm{~mol} \%\left(T_{\mathrm{m}}\right)$.

The type strain, $\mathrm{PMB} 02^{\mathrm{T}}\left(=\mathrm{KCTC} 12901^{\mathrm{T}}=\mathrm{JCM} 14648^{\mathrm{T}}\right)$, was isolated from a leaf from a tree (Platanus orientalis).

\section{Acknowledgements}

This work was supported by a grant from the National Core Research Center (R15-2003-012-02002-0), a grant from the Korean Ministry of Education and Human Resources Development and a grant (R0503443) from the BioGreen21 Program of the Rural Development Administration, Republic of Korea, to W.P. This work was also supported by the Brain Korea 21 project in 2007.

\section{References}

Anesti, V., Vohra, J., Goonetilleka, S., McDonald, I. R., Sträubler, B., Stackebrandt, E., Kelly, D. P. \& Wood, A. P. (2004). Molecular 
detection and isolation of facultatively methylotrophic bacteria, including Methylobacterium podarium sp. nov., from the human foot microflora. Environ Microbiol 6, 820-830.

Aslam, Z., Lee, C. S., Kim, K.-H., Im, W.-T., Ten, L. N. \& Lee, S. T. (2007). Methylobacterium jeotgali sp. nov., a non-pigmented, facultatively methylotrophic bacterium isolated from jeotgal, a traditional Korean fermented seafood. Int J Syst Evol Microbiol 57, 566-571.

Bousfield, I. J. \& Green, P. N. (1985). Reclassification of bacteria of the genus Protomonas Urakami and Komagata 1984 in the genus Methylobacterium (Patt, Cole, and Hanson) emend. Green and Bousfield 1983. Int J Syst Bacteriol 35, 209.

Corpe, W. A. \& Basile, D. V. (1982). Methanol-utilizing bacteria associated with green plants. Dev Ind Microbiol 23, 483-494.

Doronina, N. V., Trotsenko, Y. A., Tourova, T. P., Kuznetsov, B. B. \& Leisinger, T. (2000). Methylopila helvetica sp. nov. and Methylobacterium dichloromethanicum sp. nov.: novel aerobic facultatively methylotrophic bacteria utilizing dichloromethane. Syst Appl Microbiol 23, 210-218.

Doronina, N. V., Trotsenko, Y. A., Kuznetsov, B. B., Tourova, T. P. \& Salkinoja-Salonen, M. S. (2002). Methylobacterium suomiense sp. nov. and Methylobacterium lusitanum sp. nov., aerobic, pinkpigmented, facultatively methylotrophic bacteria. Int J Syst Evol Microbiol 52, 773-776.

Ezaki, T., Hashimoto, Y. \& Yabuuchi, E. (1989). Fluorometric deoxyribonucleic acid-deoxyribonucleic acid hybridization in microdilution wells as an alternative to membrane filter hybridization in which radioisotopes are used to determine genetic relatedness among bacterial strains. Int J Syst Bacteriol 39, 224-229.

Felsenstein, J. (2002). PHYLIP (phylogeny inference package), version 3.6a. Distributed by the author. Department of Genome Sciences, University of Washington, Seattle, USA.

Gallego, V., Garcia, M. T. \& Ventosa, A. (2005a). Methylobacterium hispanicum sp. nov. and Methylobacterium aquaticum sp. nov., isolated from drinking water. Int J Syst Evol Microbiol 55, 281-287.

Gallego, V., Garcia, M. T. \& Ventosa, A. (2005b). Methylobacterium variabile sp. nov., a methylotrophic bacterium isolated from an aquatic environment. Int J Syst Evol Microbiol 55, 1429-1433.

Gallego, V., Garcia, M. T. \& Ventosa, A. (2005c). Methylobacterium isbiliense sp. nov., isolated from the drinking water system of Sevilla, Spain. Int J Syst Evol Microbiol 55, 2333-2337.

Gallego, V., Garcia, M. T. \& Ventosa, A. (2006). Methylobacterium adhaesivum sp. nov., a methylotrophic bacterium isolated from drinking water. Int J Syst Evol Microbiol 56, 339-342.

Green, P. N. (1992). The genus Methylobacterium. In The Prokaryotes, 2nd edn, pp. 2342-2349. Edited by A. Balows, H. G. Trüper, M. Dworkin, W. Harder \& K. H. Schleifer. New York: Springer.

Green, P. N. \& Bousfield, I. J. (1983). Emendation of Methylobacterium Patt, Cole, and Hanson 1976; Methylobacterium rhodinum (Heumann 1962) comb. nov. corrig.; Methylobacterium radiotolerans (Ito \& Iizuka 1971) comb. nov., corrig.; and Methylobacterium mesophilicum (Austin \& Goodfellow 1979) comb. nov. Int J Syst Bacteriol 33, 875-877.

Green, P. N., Bousfield, I. J. \& Hood, D. (1988). Three new Methylobacterium species: M. rhodesianum sp. nov., M. zatmanii sp. nov., and M. fujisawaense sp. nov. Int J Syst Bacteriol 38, 124-127.

Hirano, S. S. \& Upper, C. D. (1991). Bacterial community dynamics. In Microbial Ecology of Leaves, pp. 271-294. Edited by J. H. Andrews \& S. S. Hirano. New York: Springer.

Jourand, P., Giraud, E., Bena, G., Sy, A., Willems, A., Gillis, M., Dreyfus, B. \& de Lajudie, P. (2004). Methylobacterium nodulans sp. nov., for a group of aerobic, facultatively methylotrophic, legume root-nodule-forming and nitrogen-fixing bacteria. Int J Syst Evol Microbiol 54, 2269-2273.

Kim, M. K., Im, W.-T., Ohta, H., Lee, M. \& Lee, S.-T. (2005). Sphingopyxis granuli sp. nov., a beta-glucosidase-producing bacterium in the family Sphingomonadaceae in alpha-4 subclass of the Proteobacteria. J Microbiol 43, 152-157.

Lidstrom, M. E. \& Chistoserdova, L. (2002). Plants in the pink: cytokinin production by Methylobacterium. J Bacteriol 184, 1818.

Madhaiyan, M., Kim, B.-Y., Poonguzhali, S., Kwon, S.-W., Song, M.-H., Ryu, J.-H., Go, S.-J., Koo, B.-S. \& Sa, T.-M. (2007). Methylobacterium oryzae sp. nov., an aerobic, pink-pigmented, facultatively methylotrophic, 1-aminocyclopropane-1-carboxylate deaminase-producing bacterium isolated from rice. Int J Syst Evol Microbiol 57, 326-331.

McDonald, I. R., Droning, N. V., Trotsenko, Y. A., McAnulla, C. \& Murrell, J. C. (2001). Hyphomicrobium chloromethanicum sp. nov. and Methylobacterium chloromethanicum sp. nov., chloromethane-utilizing bacteria isolated from a polluted environment. Int J Syst Evol Microbiol 51, 119-122.

Mesbah, M., Premachandran, U. \& Whitman, W. B. (1989). Precise measurement of the $\mathrm{G}+\mathrm{C}$ content of deoxyribonucleic acid by high-performance liquid chromatography. Int J Syst Bacteriol 39, 159-167.

Ostle, A. G. \& Holt, J. G. (1982). Nile blue A as a fluorescent stain for poly-beta-hydroxybutyrate. Appl Environ Microbiol 44, 238-241.

Patt, T. E., Cole, G. C. \& Hanson, R. S. (1976). Methylobacterium, a new genus of facultatively methylotrophic bacteria. Int J Syst Bacteriol 26, 226-229.

Sasser, M. (1990). Identification of bacteria by gas chromatography of cellular fatty acids, MIDI Technical Note 101. Newark, DE: MIDI.

Stackebrandt, E. \& Goebel, B. M. (1994). Taxonomic note: a place for DNA-DNA reassociation and 16S rRNA sequence analysis in the present species definition in bacteriology. Int J Syst Bacteriol 44, 846-849.

Stanier, R. Y., Palleroni, N. J. \& Doudoroff, M. (1966). The aerobic pseudomonads: a taxonomic study. J Gen Microbiol 43, 159-271.

Thompson, J. D., Higgins, D. G. \& Gibson, T. J. (1994). Clustal w: improving the sensitivity of progressive multiple sequence alignment through sequence weighting, position-specific gap penalties and weight matrix choice. Nucleic Acids Res 22, 4673-4680.

Urakami, T., Araki, H. H., Suzuki, K. \& Komogata, K. (1993). Further studies of the genus Methylobacterium and description of Methylobacterium aminovorans sp. nov. Int J Syst Bacteriol 43, 504-513.

Van Aken, B., Peres, C. M., Lafferty-Doty, S., Yoon, J. M. \& Schnoor, J. L. (2004). Methylobacterium populi sp. nov., a novel aerobic, pinkpigmented, facultatively methylotrophic, methane-utilizing bacterium isolated from poplar trees (Populus deltoides $\times$ nigra DN34). Int J Syst Evol Microbiol 54, 1191-1196.

Wayne, L. G., Brenner, D. J., Colwell, R. R., Grimont, P. A. D., Kandler, O., Krichevsky, M. I., Moore, L. H., Moore, W. E. C., Murray, R. G. E. \& other authors (1987). International Committee on Systematic Bacteriology. Report of the ad hoc committee on reconciliation of approaches to bacterial systematics. Int J Syst Bacteriol 37, 463-464.

Wood, A. P., Kelly, D. P., McDonald, I. R., Jordan, S. L., Morgan, T. D., Khan, S., Murrell, J. C. \& Borodina, E. (1998). A novel pinkpigmented facultative methylotroph, Methylobacterium thiocyanatum sp. nov., capable of growth on thiocyanate or cyanate as sole nitrogen sources. Arch Microbiol 169, 148-158. 